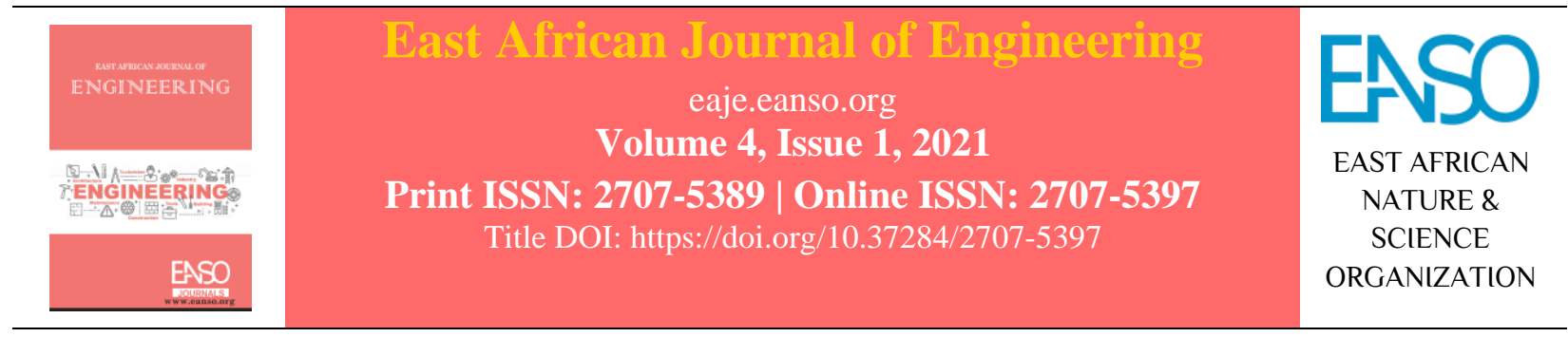

Original Article

\title{
A Comparison Between The (Design-Build DB) and (Design-Bid-Build DBB) Approaches Used in the Jordanian Construction Sector and Clarify the Risks Associated with Each Approach.
}

\author{
Sharaf Al-Deen Waleed AL-Smadi, MSc ${ }^{l^{*}}$, Abdalrahman Hammoudah Yousef Alhndawi, MSc ${ }^{l}$ \\ ${ }^{1}$ Department of Mechanical and Manufacturing Engineering, Faculty of Engineering, Universiti Putra Malaysia, 43400 Serdang, \\ Selangor, Malaysia, 21555. \\ * Author for Correspondence ORCID: 0000-0003-1442-0359; Email: sharafaldeensmadi1995@ gmail.com.
}

Article DOI: https://doi.org/10.37284/eaje.4.1.442

\section{Publication Date: ABSTRACT}

19 October 2021 The continual need for building in developing economies and countries such as Jordan increases the obstacles and problems faced by Project

Keywords: Management Units in completing projects on time, with quality assurance, and at lower prices. However, as more and more new types of project

\section{Construction Management,} management approaches such as (Design-Bid DB) are introduced, the Risks,

Design-Build, binding conditions of contracts are growing tougher in order to reduce risks during project execution. In this paper, the researcher tries to provide Design-Bid-Build, a fair comparison between (Design-Bid-Build DBB) and (Design-Build Construction Safety. DB) approaches which are already used in the construction project in Jordan and offering a good vision for both owners and contractors equally.

\section{APA CITATION}

AL-Smadi, S. A. W., Alhndawi, A. H. Y. (2021). A Comparison Between The (Design-Build DB) and (Design-Bid-Build DBB) Approaches Used in the Jordanian Construction Sector and Clarify the Risks Associated with Each Approach East African Journal of Engineering, 4(1), 1-12. https://doi.org/10.37284/eaje.4.1.442

\section{CHICAGO CITATION}

AL-Smadi, Sharaf Al-Deen Waleed, Abdalrahman Hammoudah Yousef Alhndawi. 2021. "A Comparison Between The (DesignBuild DB) and (Design-Bid-Build DBB) Approaches Used in the Jordanian Construction Sector and Clarify the Risks Associated with Each Approach". East African Journal of Engineering 4 (1), 1-12. https://doi.org/10.37284/eaje.4.1.442.

\section{HARVARD CITATION}

AL-Smadi, S. A. W., Alhndawi, A. H. Y. (2021) “A Comparison Between The (Design-Build DB) and (Design-Bid-Build DBB) Approaches Used in the Jordanian Construction Sector and Clarify the Risks Associated with Each Approach", East African Journal of Engineering, 4(1), pp. 1-12. doi: 10.37284/eaje.4.1.442.

\section{IEEE CITATION}

S. A. W., AL-Smadi., A. H. Y. Alhndawi. "A Comparison Between The (Design-Build DB) and (Design-Bid-Build DBB) Approaches Used in the Jordanian Construction Sector and Clarify the Risks Associated with Each Approach," EAJE, vol. 4, no. 1, pp. 1-12, Oct. 2021.

1 | This work is licensed under a Creative Commons Attribution 4.0 International License. 


\section{MLA CITATION}

AL-Smadi, Sharaf Al-Deen Waleed, Abdalrahman Hammoudah Yousef Alhndawi. “A Comparison Between The (Design-Build DB) and (Design-Bid-Build DBB) Approaches Used in the Jordanian Construction Sector and Clarify the Risks Associated with Each Approach.” East African Journal of Engineering, Vol. 4, no. 1, Oct. 2021, pp. 1-12, doi:10.37284/eaje.4.1.442.

\section{INTRODUCTION}

The regular design-bid-build (DBB) approach is used extensively in the Hashemite Kingdom of Jordan's construction sector. A project is divided into several packages, each of which is issued to a separate unit that works with the owners to complete the project (Alhusban, 2018).

According to (Hillebrandt, 2000) the feasibility assessments, surveys, and construction designs are prepared, as well as bidding to choose construction companies/contractors and/or equipment providers. Independent contractors are allocated work by the client/owner. As a result, the risks associated with project execution will be carried equitably by all parties engaged in the project, first from start to the completion, approval, and delivery of the tasks.

The project's main focus is on the owner, who is accountable for the project's quality, progress, and expenses. However, the fact that independent contractors enter the project worksite only after performing design and economic evaluation lengthens the process. Furthermore, construction teams take perhaps too much time for studying the designs, and construction activity necessitate collaboration between owners, construction teams, and design consultants, which may lead to delaying the project's overall duration (Barbosa, Woetzel, \& Mischke, 2017; Reyes, San-José, Cuadrado, \& Sancibrian, 2014).

Since the independent contractors are simply responsible for their own work, that makes them lacking initiative, flexibility, and originality, and they become reliant on the consultants. Because of their ownership in all aspects of consultancy and construction services, many owners from diverse sectors of the economy have recently actually chosen the design-build (DB) general contractor form for their projects, which makes domestic construction firms have a great benefit, while consultants have access to the new entire form of project management with high professionalism and expertise (Guttiman, 2000).

This paper is going to presents a fair comparison between (DB and DBB) or (Design-Build and Design-Bid-Build) approaches which are used widely in construction projects in the Hashemite Kingdom of Jordan and provide a general overview of (DB) approach and also highlight the significant risk factors for (DB) projects in the construction industry in Jordan based on the local market constraints forced by the economic and political situations.

\section{Research Background}

The classic (Design- Bid- Build) DBB projects imp lementation method is usually compared to a sort of new approach called (Design-Build) (DB). In the (DBB) approach, the owner employs two independent units to execute the design and construction tasks (Hale, Shrestha, Gibson Jr, \& Migliaccio, 2009; Ling, Chan, Chong, \& Ee, 2004).

In (Design- Bid- Building) method, owners/clients hire independent contractors to design and implement the project. The design, bid, and construction operations are all done in this order; therefore, the design must always be done before bidding as well as electing a contractor to start the implementation stage.

Based on (Eastman, Eastman, Teicholz, Sacks, \& Liston, 2011), the implementation of the work begins when the construction contractors have been chosen. The connection between the design-builder and construction contractors is fully independent in (DBB) method.

2 | This work is licensed under a Creative Commons Attribution 4.0 International License. 
On the other hand, the subcontractors are involved in (Design-Build) approach to help contractors with project execution. At the same time, the same contractor is in charge of both design and building stages (Chang, Shen, \& Ibbs, 2010).

Figure 1: Typical contractual framework of DBB and DB projects

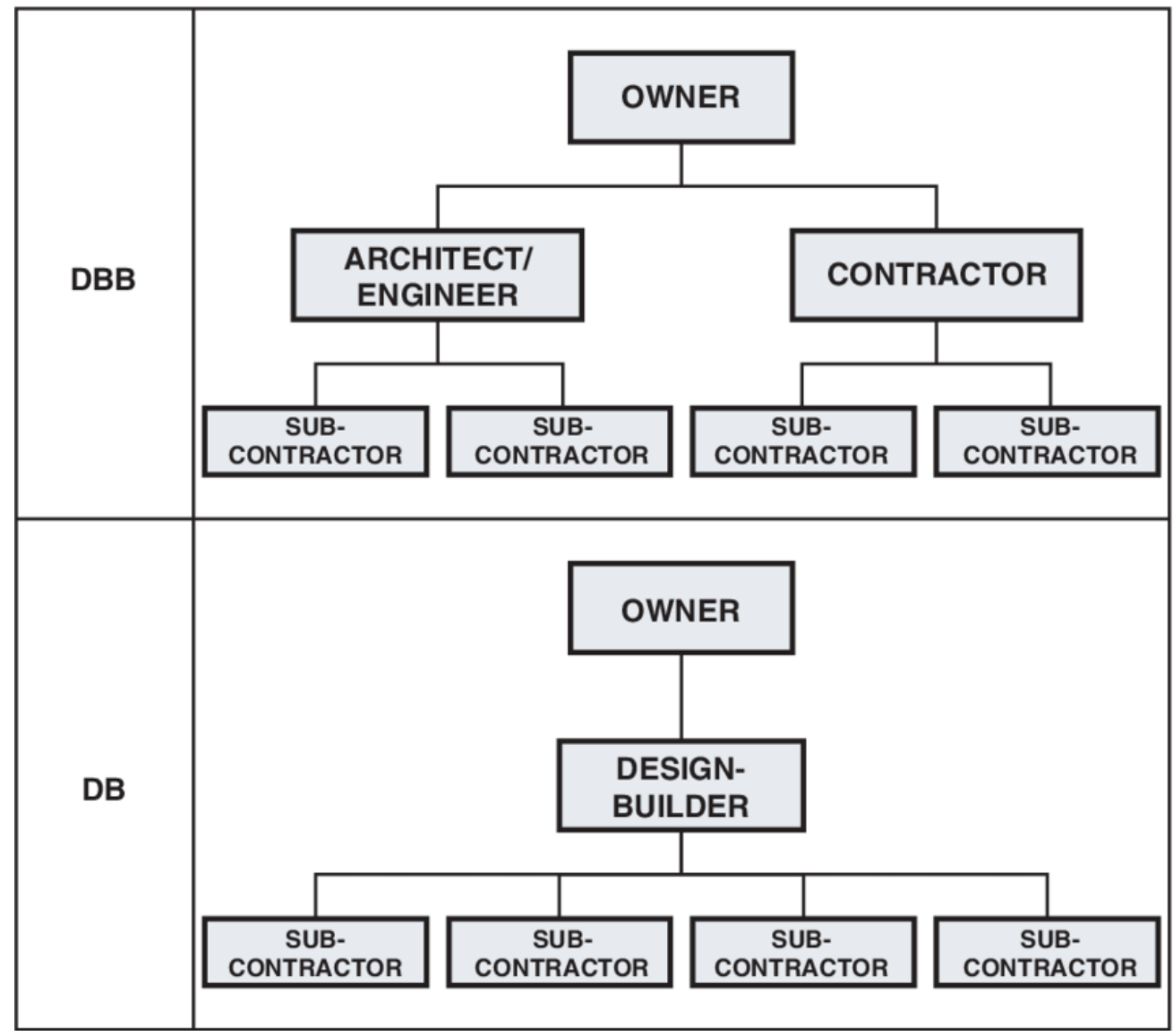

Figure 1 shows both models of project management for (Design-Bid-Build) approaches and clarifies the difference in both structures (Shrestha, Migliaccio, O'Connor, \& Gibson Jr, 2007).

To share some of the duties in construction sites, the (Design-Build) contractor may employ the consultant and/or construction subcontractors. All design and building tasks of the (Design-Build) project, including work done by subcontractors remain the responsibility of the officially hired contractor. Throughout the project life cycle process, this assists the owner/client in simplifying the activities in the management process (Songer \& Molenaar, 1996).
As an outcome, the probability of orders of design changes, delays in the delivery deadline, and risk related to design stages like extreme discrepancy in design and design drawing (Hiyassat, Alkasagi, ElMashaleh, \& Sweis, 2020) to owners will be minimised as much as possible. Furthermore, because the construction design is done by a separate unit, the building contractors will be notified of the plans at an early stage. As a result, even if the design isn't finished, the contractor may start working on the project, reducing the execution time and allowing the owner to start using the project earlier (Soomro, Memon, Chandio, Sohu, \& Soomro, 2019).

3 | This work is licensed under a Creative Commons Attribution 4.0 International License. 
Furthermore, disagreements and disputes between design-builders and construction contractors, Errors in the project execution process will be considerably minimised because of the continuity from design to construction. Because the design and construction divisions are part of the same organisation, they can better coordinate and make design changes even during the execution/construction stage (Kymmell, 2008).

Figure 2: (Design-Bid-Build) Advantages-Disadvantages

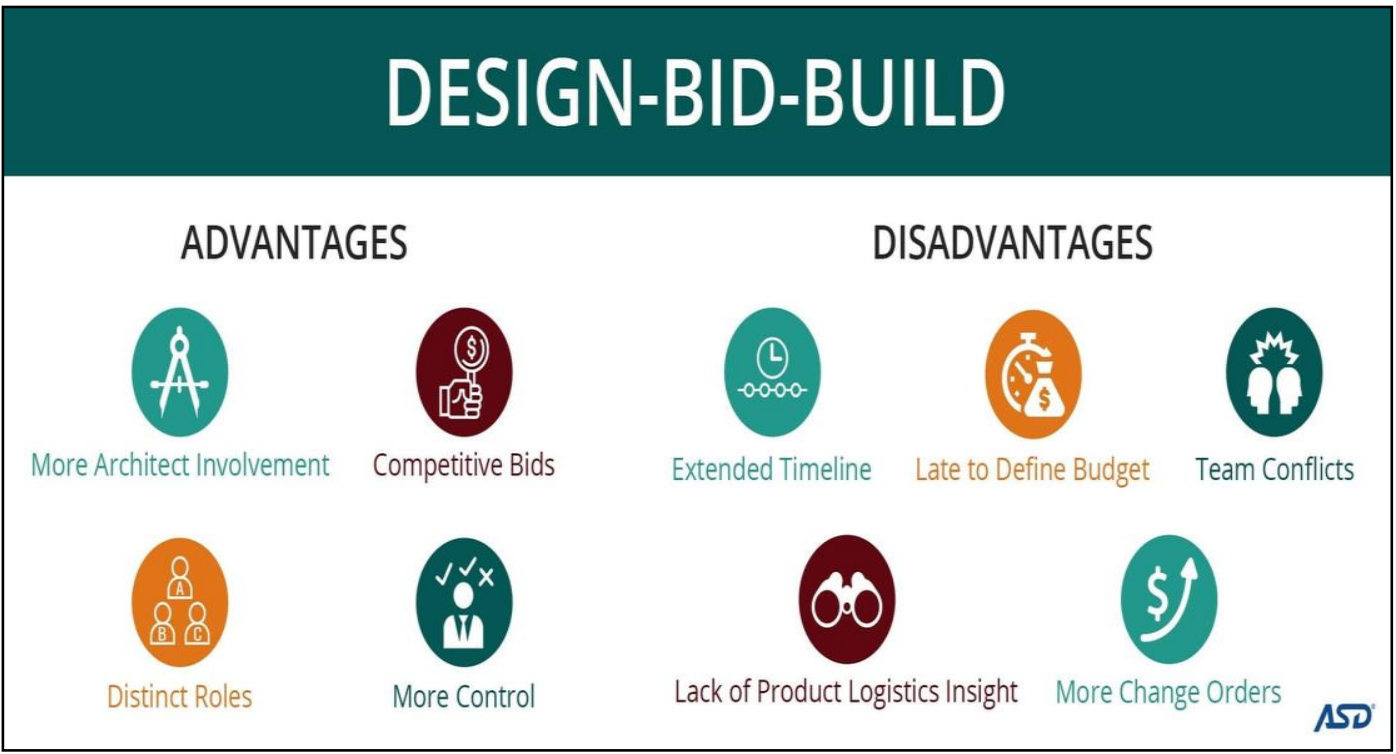

Figure 3: (Design-Build) Advantages-Disadvantages

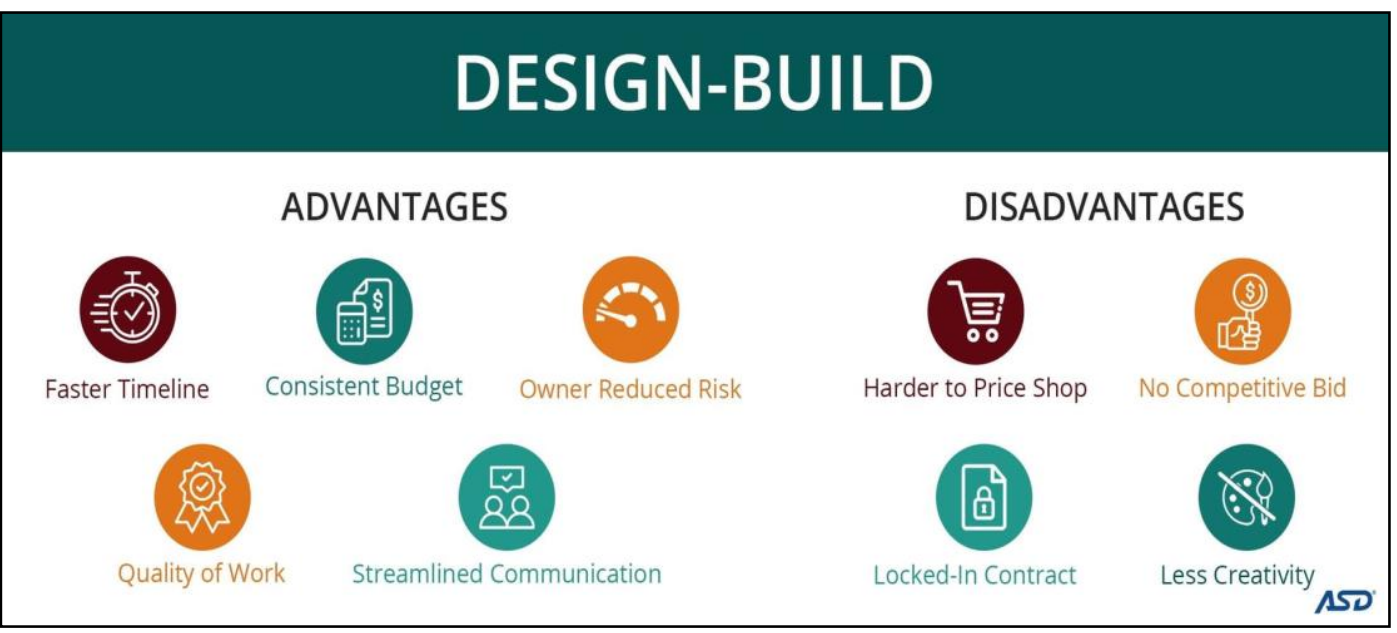

Figure 2 and Figure 3 show the advantages and between the two styles that will help the owner to disadvantages for both (DB vs DBB) approaches, decide which is the best system for his project. both methods result in a solid completed building on Those differences range from cost to project length time. However, there are some key differences (Otwell, 2019; Perlberg, 2021).

4 | This work is licensed under a Creative Commons Attribution 4.0 International License. 


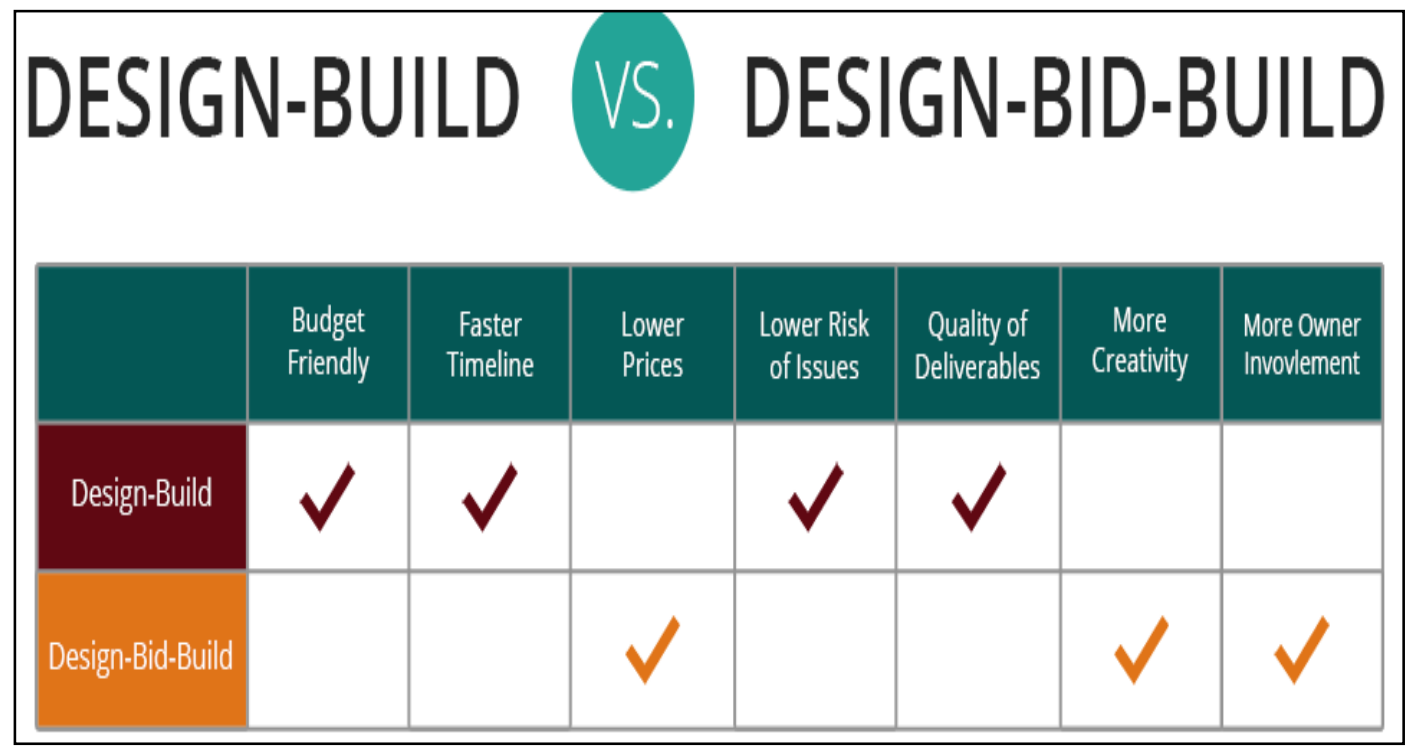

And Figure 4 (Otwell, 2019) summarises the whole comparison between (DBB) and (DB) approaches.

\section{RISK FACTORS RELATED TO CONSTRUCTION SITES IN THE HASHEMITE KINGDOM OF JORDAN}

Threats and risks associated with economics and finance (Commercial), political, contracts problems, design, construction stage, and other unavoidable risks can all be defined as risks in construction projects. (P. T. Nguyen \& Nguyen, 2020) (Öztaş \& Ökmen, 2004). In this paper, the researcher will discuss six different groups of risks factors related to the construction sites in Jordan.

\section{Economics and Finance (Commercial) Risks}

The most frequent technique of determining a project's ability to meet the financial targets established by stakeholders and participants is to analyse its financial feasibility. Previous initiatives have highlighted financial market risks and currency rate changes as negative variables. In addition, inflation and interest rates are significant risk factors (Almarri \& Abu-Hijleh, 2017). Inflation and interest rate fluctuations do, impact the construction industry's level of uncertainty (Almarri \& Abu-Hijleh, 2017).
Inflation may significantly affect the cost of supplies, equipment, and labour in a project. When an economic situation is unstable, it is difficult to raise investment rates for projects, and investors may be forced to reschedule projects due to a shortage of funds (Leahy \& Whited, 1996).

In Jordan, there are a lot of financial constraints and risks that have a negative impact on construction projects such as limited capital(budget), financial problems due to environmental protection, need for a land appraisal, and third-party tort liability/ Thirdparty intervention/ Third-party delay (Bu-Qammaz, 2015; Heravi \& Hajihosseini, 2012).

\section{Politics and Regulations Risks}

Political factors have an impact on all state agency acts at the national, regional, and local levels. Political risks influence project investment attractiveness and include risks associated with project investment proceeding without being slowed by trade conflicts or demonstrations. Corruption, government involvement, approval delays, and government relations / 
Intervention/instability are all examples of political risks in the case of Jordan (El-adaway, 2008).

As a result of the political situation that Jordan has been exposed to, especially after the waves of humanitarian refugees from surrounding countries such as Syria and Iraq, there has been huge inflation in the numbers of skilled labourers in various sectors, especially in the construction sector(Fakih \& Ibrahim, 2016). This led to an increase in supply and a decrease in demand, which caused a decrease in their average income rates and their increased dependence on the Jordanian government to help them secure their daily needs. (The UN Refugee Agency, 2021) and figure 5 shows the details.

Figure 5: Numbers of refugees and their countries of origin in Jordan until (2021)

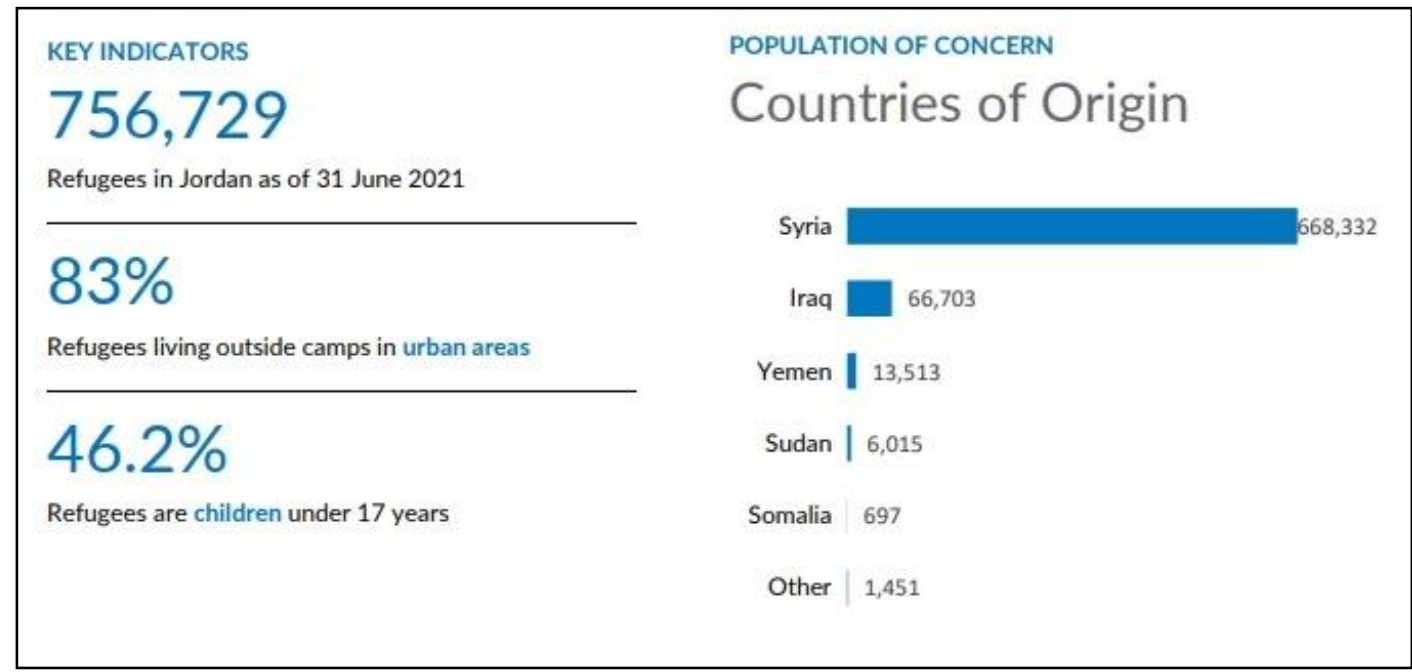

\section{Contract Problems Risks}

Lack of accountability and transparency in the bidding stage, contradictory or incomplete contracts, incorrect contract signing, unfair assignment of obligations and risks, and unsuitable contract quotations associated with the bidding process and project assessment are all examples of this set of contract problems and risks (Creedy, 2006). Due to a lack of integrity and fraud in bidding, unskilled and inexperienced contractors are chosen, who are unable to verify that the design and construction work is completed in accordance with the specifications, generating issues throughout construction (Lines, Shalwani, \& Smithwick, 2018). In the case of Jordan, the main problems related to contracts are Poorly tailored contract forms, Conflict in contract documents, and unclear contract clauses and conditions (Bu-Qammaz, 2015; Sameh
M El-Sayegh \& Mansour, 2015; Liu, Zhao, \& Yan, 2016).

\section{Design Risks}

Design builders, of course, suffer from design risks and problems, but individuals participating in the projects, such as owners or contractors, have generic design risks as well, based on their roles and responsibilities (Smith, Merna, \& Jobling, 2014). This is due to the fact that in Design-Build (DB) projects, design groups no longer work only for the owner and instead collaborate with construction groups, leading to less communication with the client/owner. As a result, there are likely to be misunderstandings or late modifications with the owner. Because the aims and scope of a project are unclear, it may be essential to modify them throughout the execution phase (Likhitruangsilp \& Harinthajinda, 2008; Liu, Xie, Xia, \& Bridge, 2017; P. Nguyen \& Likhitruangsilp, 2017).

6 | This work is licensed under a Creative Commons Attribution 4.0 International License. 
For the Jordanian construction sector, the most critical problems related to the stage of design change in design and late design changes (Goh, Abdul-Rahman, \& Abdul Samad, 2013), In addition to poor design, design error, an extreme discrepancy in design and design drawing and inadequate allocated time (El-adaway, 2008; Sarvari, Valipour, Yahaya, \& Noor, 2014).

\section{Construction Stage Risks}

Construction risks are inherent risks during the building stage of a Design-Build (DB) project in Jordan. These Risks include material, labour, and equipment unavailability (resourcing), labour and material price fluctuation (price adjustments), the discrepancy in applied and approved payment, productivity decrease (poorly trained skilled labour), construction complexity, and finally, excessive contract variation (Goh et al., 2013; Liu et al., 2016; Wang, Tang, Du, Duffield, \& Wei, 2016; Zhang \& Bai, 2013).

If the project's quality isn't assured, the contractor may encounter several challenges during the building process. To reduce risks, management and inspection of the design papers' rationality in comparison to geological documents, quality of supervision, control, and assurance, and the contractor's suggested construction technique are all essential (Fernandez, 2014).

According to (AL-Smadi, Supeni, \& Voon, 2021) initiating the requirement of safety for mitigation of the associated accidents and the risks of life loss and injuries at construction sites is an essential requirement to reduce the safety accidents related to construction stage risks in the Hashemite Kingdom of Jordan.

\section{Other Unavoidable Risks}

According to (Liu et al., 2016) and (Goh et al., 2013), the protection of proprietary information and late handing over the project due to the inspection of numerous parties are considered risks we have to take in our consideration while choosing the project management approaches.

\section{METHODOLOGY}

Aiming to accurately assess the risk expected effect on the project workflow, we must understand two major aspects: the frequency or probability of occurrence and the intensity of the consequences. Risk is sometimes defined as a mix of the consequences of an event and the probability of that event occurring by calculating several terms like risk (priority) index (RI) and relative importance index (RII). In this study, the results will be adopted from (Chan, Yeung, Yu, Wang, \& Ke, 2011; Sameh Monir El-Sayegh, 2008; Sameh M El-Sayegh \& Mansour, 2015; Hiyassat et al., 2020).

The risk (priority) index is determined for each risk component using the equation below, which takes into account the related risk probability and risk effect:

$\mathrm{R}=(1-\quad \mathrm{C} / 100 * \mathrm{Q} / 100 * \mathrm{~S} / 100) \quad * 100$ .......................... (1)

$\mathrm{R}$ will never be greater than $100 \%$. If a negative number is calculated (due to having a Completeness greater than $100 \%$ ), round $\mathrm{R}$ up to 0 .

$\mathrm{RII}=\left(\sum \mathrm{w}\right) / \mathrm{AN}=(5 \mathrm{n} 5+4 \mathrm{n} 4+3 \mathrm{n} 3+2 \mathrm{n} 2+1 \mathrm{n} 1) / 5 \mathrm{~N}$ (2)

(Tam \& Le, 2006) indicate $w$ is the weighting given to each factor by the respondent, ranging from 1 to 5. for example, $\boldsymbol{n}=$ number of respondents for little important, $\mathrm{n}_{2}=$ number of respondents for some important, $\boldsymbol{n 3}=$ number of respondents for quite important, $\boldsymbol{n}=$ number of respondents for important, $\mathrm{ns}=$ number of respondents for very important). $\boldsymbol{A}$ is the highest weight (i.e., 5 in the study) and $N$ is the total number of respondents. The relative importance index ranges from 0 to 1 (Kaushik and Sahil, 2017).

7 | This work is licensed under a Creative Commons Attribution 4.0 International License. 


\section{RESULTS AND DISCUSSION}

As mentioned earlier in the methodology section, the significant risks in construction projects in Jordan will be determined based on previous studies like (Sameh M El-Sayegh \& Mansour, 2015; Hiyassat et al., 2020) to help owners to decide which approach (DBB or DB) is more suitable for their own projects to gain the highest profitability with the lowest cost, time and effort.

Figure 6: Top 10 significant risks in construction projects in Jordan

\begin{tabular}{|llll|}
\hline Rank & \multicolumn{1}{c}{ Risk } & $\begin{array}{c}\text { Risk code } \\
\text { (Identifier) }\end{array}$ & $\begin{array}{c}\text { Risk } \\
\text { Index }\end{array}$ \\
\hline 1 & Delay in clients' payments & $\mathrm{R} 20$ & 11.4 \\
2 & $\begin{array}{l}\text { Poorly tailored contract forms/ Conflict in } \\
\text { contract documents/ Undear contract }\end{array}$ & $\mathrm{R} 41$ & 11.2 \\
& $\quad$ Clauses and conditions & & \\
3 & Competition & $\mathrm{R} 34$ & 11.1 \\
4 & Delay in approval/Permits & $\mathrm{R} 40$ & 11.0 \\
5 & Default by subcontractors & $\mathrm{R} 59$ & 10.9 \\
6 & Unclear specifications & $\mathrm{R} 44$ & 10.9 \\
7 & Material price fluctuation(Price adjustments) & $\mathrm{R} 53$ & 10.9 \\
8 & Different construction standards & $\mathrm{R} 42$ & 10.8 \\
9 & Change in design/ Late design changes & $\mathrm{R} 48$ & 10.8 \\
10 & Poor design/design error/ Extreme Discrepancy & $\mathrm{R} 47$ & 10.6 \\
& in desiqn and desiqn drawinq & & \\
\hline
\end{tabular}

Figure 7: Top 10 significant risks in construction projects in similar studies

\begin{tabular}{|llll|}
\hline Rank & \multicolumn{1}{c}{ El-Sayegh and Mansour (2015) } & \multicolumn{1}{c|}{ Cl-Sayegh (2008) } & \multicolumn{1}{c|}{ Chan et al. (2011) } \\
\hline 1 & Inefficient planning & Inflation and sudden changes in prices & Government intervention \\
2 & Unexpected underground utilities & Owners' unreasonably imposed tight schedule & Government corruption \\
3 & Quality and integrity of design & Subcontractors' poor performance and management & Poor public decision-making process \\
4 & Delays in the approvals of submittals & Delay of material supply by suppliers & Financing risk \\
5 & Delays in expropriations & Change of design required by owners & Imperfect law and supervision system \\
6 & Delays in obtaining no object certificates (NOCs) from authorities & Owners' improper intervention during construction & Operation cost overrun \\
7 & Poor coordination & Shortage in manpower supply and avaliability & Interest rate fluctuation \\
8 & Inadequate safety measures & Delays in approvals & Public credit \\
9 & Delay in payments & Lack or departure of qualified staff & Completion risk \\
10 & Material, labor, and equipment resourcina & Shortage in material supply and avalilability & Inflation \\
\hline
\end{tabular}

A total of 10 risk factors from 8 different risk groups in Jordanian construction projects have been identified as an outcome of the literature review (Chan et al., 2011; Sameh Monir El-Sayegh, 2008; Sameh M El-Sayegh \& Mansour, 2015; Hiyassat et al., 2020). The most critical risk has been identified. The following is a breakdown of the top risks and problems.
- Delay in clients' payments is the highest-ranked risk in the Jordanian construction sector and this risk factor is from the group of economics and finance group. Since the (Design-Build DB) approach have a solid consistent budget that means (DB) is a better approach to avoid this risk.

8 | This work is licensed under a Creative Commons Attribution 4.0 International License. 
- Poorly tailored contract forms/ Conflict in contract documents/ Unclear contract clauses and conditions are risk factors from the group of contract problems group. Since the (DesignBuild DB) approach have a disadvantage of locked-in contracts that means (Design-BidBuild DBB) is a better approach to avoid this risk.

- Competition risk is a very popular risk among all commercial and industrial sectors and it belongs to Socio- economic group. Since the (DesignBuild DB) approach ensuring a better quality of work and the (Design-Bid-Build DBB) approach provides a higher competitive bid that means it's tied for both approaches and makes the decision refer to the owner based on his needs.

- Delay in approval/Permits is a risk factor from the group of Politics and Regulations group. Since the (Design-Build DB) approach has a faster timeline to processing that means $(\mathrm{DB})$ is a better approach to avoid this risk.

- Default by subcontractors is a risk factor from the group of incompetency of other project participants. Since the (Design-Build DB) approach uses one direct main contractor that means (DB) is a better approach to avoid this risk for the owner.

- Unclear specifications are one of the most conflicting factors between the owner and contractor from the Project specification and standard problems. Since one of the major problems in (Design-Bid-Build DBB) approach is team conflicts that mean (Design-Build DB) is a better approach to avoid this risk.

- Material price fluctuation (Price adjustments) risk and belongs to the construction stage and it happens all the time. Since the (Design-Build DB) approach have a solid consistent budget that means (DB) is a better approach to avoid this risk.
- Different construction standards related to the group of Project specifications and standard problems. (Design-Build DB) provide higher work quality so it is more suitable to avoid this risk.

- Change in design/ Late design changes risk from the group of design changes. Since the (DesignBid-Build DBB) have more changes order that means (Design-Build DB) is a better approach to avoid this risk.

- Poor design, design error, an extreme discrepancy in design, and design drawing from design changes risk group happen usually because of poor communication between stockholders and since the (Design-Build DB) approach gives stronger communication channels, its means (DB) better to avoid this risk.

Based on that, it's clear the (Design-Build DB) approach is more effective in facing or even avoiding the most significant risks in the Jordanian construction sector.

\section{CONCLUSION}

The risk factors influencing the implementation stage of Design-Build projects in the construction sector in the Hashemite Kingdom of Jordan are mentioned and discussed in this research paper. The top 10 essential risk variables, in descending order of significance, were discovered to be: delay in clients' payments, poorly tailored contract forms/ conflict in contract documents/ unclear contract clauses and conditions, competition delay in approval/permits is a risk factor default by subcontractors, unclear specifications, material price fluctuation (price adjustments), different construction standards poor design, design error and extreme discrepancy in design and design drawing.

Based on the comparison done by the researcher we can conclude that the (Design-Building DB) is the most effective approach to avoid the most

9 | This work is licensed under a Creative Commons Attribution 4.0 International License. 
significant risks in the Jordanian construction sector.

\section{REFERENCES}

AL-Smadi, S. A.-D. W., Supeni, E. E., \& Voon, W. S. (2021). A Study on Safety and Health Good Practices at Construction Sector in Jordan. East African Journal of Engineering, 3(1), 57-71.

Alhusban, M. (2018). Conceptual Procurement Framework for Building Information Modelling Uptake to Enhance Buildings' Sustainability Performance in the Jordanian Public Sector. University of Portsmouth.

Almarri, K., \& Abu-Hijleh, B. (2017). Critical Success Factors for Public Private Partnerships in the UAE Construction Industry-A Comparative Analysis between the UAE and the UK. Journal of Engineering, Project \& Production Management, 7(1).

Barbosa, F., Woetzel, J., \& Mischke, J. (2017). Reinventing Construction: A Route of Higher Productivity. Retrieved from

Bu-Qammaz, A. S. (2015). Risk Management Model for International Public Construction Joint Venture Projects in Kuwait: The Ohio State University.

Chan, A. P., Yeung, J. F., Yu, C. C., Wang, S. Q., \& Ke, Y. (2011). Empirical study of risk assessment and allocation of public-private partnership projects in China. Journal of Management in Engineering, 27(3), 136-148.

Chang, A. S., Shen, F.-Y., \& Ibbs, W. (2010). Design and construction coordination problems and planning for design-build project new users. Canadian journal of civil engineering, 37(12), $1525-1534$

Creedy, G. D. (2006). Risk factors leading to cost overrun in the delivery of highway construction projects. Queensland University of Technology.
Eastman, C. M., Eastman, C., Teicholz, P., Sacks, R., \& Liston, K. (2011). BIM handbook: A guide to building information modeling for owners, managers, designers, engineers and contractors: John Wiley \& Sons.

El-adaway, I. H. (2008). Construction dispute mitigation through multi-agent based simulation and risk management modeling: Iowa State University.

El-Sayegh, S. M. (2008). Risk assessment and allocation in the UAE construction industry. International journal of project management, 26(4), 431-438.

El-Sayegh, S. M., \& Mansour, M. H. (2015). Risk assessment and allocation in highway construction projects in the UAE. Journal of Management in Engineering, 31(6), 04015004.

Fakih, A., \& Ibrahim, M. (2016). The impact of Syrian refugees on the labor market in neighboring countries: empirical evidence from Jordan. Defence and Peace Economics, 27(1), 64-86.

Fernandez, R. H. F. (2014). Strategies to reduce the risk of building collapse in developing countries. Strategies.

Goh, C. S., Abdul-Rahman, H., \& Abdul Samad, Z. (2013). Applying risk management workshop for a public construction project: Case study. Journal of construction engineering and management, 139(5), 572-580.

Guttiman, D. (2000). Public purpose and private service: The twentieth century culture of contracting out and the evolving law of diffused sovereignty. Admin. L. Rev., 52, 859.

Hale, D. R., Shrestha, P. P., Gibson Jr, G. E., \& Migliaccio, G. C. (2009). Empirical comparison of design/build and design/bid/build project delivery methods. Journal of construction engineering and management, 135(7), 579-587.

10 | This work is licensed under a Creative Commons Attribution 4.0 International License. 
Heravi, G., \& Hajihosseini, Z. (2012). Risk allocation in public-private partnership infrastructure projects in developing countries: case study of the Tehran-Chalus toll road. Journal of Infrastructure Systems, 18(3), 210217.

Hillebrandt, P. M. (2000). Economic theory and the construction industry: Springer.

Hiyassat, M. A., Alkasagi, F., El-Mashaleh, M., \& Sweis, G. J. (2020). Risk allocation in public construction projects: the case of Jordan. International Journal of Construction Management, 1-11.

Kaushik and Sahil, 2017. How to calculate Relative Importance Index using Likert's scale.

Kymmell, W. (2008). Building Information Modeling: Planning and Managing Construction Projects with 4D CAD and Simulations (McGraw-Hill Construction Series): McGraw-Hill Education.

Leahy, J. V., \& Whited, T. M. (1996). The effect of uncertainty on investment: Some stylized facts. Journal of Money, Credit and Banking, 28(1), 64-83.

Likhitruangsilp, V., \& Harinthajinda, P. (2008). Assessment of contractors' risk response in tunneling projects. Paper presented at the Eleventh East Asia-Pacific Conference on Structural Engineering and Construction, Taipei, Taiwan.

Lines, B., Shalwani, A., \& Smithwick, J. (2018). Effectiveness of qualifications-based selection criteria in design-build and construction manager at risk procurements: An empirical analysis. Paper presented at the Construction Research Congress, New Orleans, Louisiana.

Ling, F. Y. Y., Chan, S. L., Chong, E., \& Ee, L. P. (2004). Predicting performance of design-build and design-bid-build projects. Journal of construction engineering and management, 130(1), 75-83.

Liu, J., Xie, Q., Xia, B., \& Bridge, A. J. (2017). Impact of design risk on the performance of design-build projects. Journal of construction engineering and management, 143(6), 04017010.

Liu, J., Zhao, X., \& Yan, P. (2016). Risk paths in international construction projects: Case study from Chinese contractors. Journal of construction engineering and management, 142(6), 05016002.

Nguyen, P., \& Likhitruangsilp, V. (2017). Identification risk factors affecting concession period length for public-private partnership infrastructure projects. International Journal of Civil Engineering and Technology, 8(6), 342348.

Nguyen, P. T., \& Nguyen, P.-C. (2020). Risk Management in Engineering and Construction. Engineering, Technology \& Applied Science Research, 10(1), 5237-5241.

Öztaş, A., \& Ökmen, Ö. (2004). Risk analysis in fixed-price design-build construction projects. Building and environment, 39(2), 229-237.

Reyes, J. P., San-José, J. T., Cuadrado, J., \& Sancibrian, R. (2014). Health \& Safety criteria for determining the sustainable value of construction projects. Safety science, 62, 221232.

Sarvari, H., Valipour, A., Yahaya, N., \& Noor, N. M. (2014). Risk identification and assessment in Malaysian public-private partnership projects Vulnerability, uncertainty, and risk: Quantification, mitigation, and management (pp. 436-445).

Shrestha, P. P., Migliaccio, G. C., O'Connor, J. T., \& Gibson Jr, G. E. (2007). Benchmarking of large design-build highway projects: One-to-

11 | This work is licensed under a Creative Commons Attribution 4.0 International License. 
one comparison and comparison with designbid-build projects. Transportation Research Record, 1994(1), 17-25.

Smith, N. J., Merna, T., \& Jobling, P. (2014). Managing risk in construction projects: John Wiley \& Sons.

Songer, A. D., \& Molenaar, K. R. (1996). Selecting design-build: Public and private sector owner attitudes. Journal of Management in Engineering, 12(6), 47-53.

Soomro, F. A., Memon, M. J., Chandio, A. F., Sohu, S., \& Soomro, R. (2019). Causes of time overrun in construction of building projects in Pakistan. Engineering, Technology \& Applied Science Research, 9(1), 3762-3764.

Tam, W., \& Le, K. N. (2006). Environmental assessment by power spectrum. Paper presented at the Joint International Conference on Construction Culture, Innovations, and Management. Dubai, The British University in Dubai.

Wang, T., Tang, W., Du, L., Duffield, C. F., \& Wei, Y. (2016). Relationships among risk management, partnering, and contractor capability in international EPC project delivery. Journal of Management in Engineering, 32(6), 04016017.

Zhang, W., \& Bai, Y. (2013). Risk allocation and dispute resolution mechanisms in chinese public projects: an empirical study ICCREM 2013: Construction and Operation in the Context of Sustainability (pp. 637-649). 